\title{
UNIVERSITYOF
}

FORWARD

THINKING

WESTMINSTER用

WestminsterResearch

http://www.westminster.ac.uk/westminsterresearch

Money and Audit Practice in the UK Public Sector

Alwardat, Y., Benamraoui, A. and Rieple, A.

This is the peer reviewed version of the following article: Alwardat, Y., Benamraoui, A. and Rieple, A. (2015) Money and Audit Practice in the UK Public Sector, International Journal of Auditing, 19, p. 206-217, which has been published in final form at https://dx.doi.org/10.1111/ijau.12037.

This article may be used for non-commercial purposes in accordance with Wiley Terms and Conditions for Self-Archiving.

The WestminsterResearch online digital archive at the University of Westminster aims to make the research output of the University available to a wider audience. Copyright and Moral Rights remain with the authors and/or copyright owners.

Whilst further distribution of specific materials from within this archive is forbidden, you may freely distribute the URL of WestminsterResearch: ((http://westminsterresearch.wmin.ac.uk/)).

In case of abuse or copyright appearing without permission e-mail repository@westminster.ac.uk 


\section{Value for Money and Audit Practice in the UK Public Sector}

Summary: This paper uses both role theory and audit expectations gap theory to critically evaluate the ability of Value for Money (VfM) audit procedures to improve performance in UK public sector organisations. The paper reports on an empirical study of seventeen auditors and twenty two representatives of VfM client organisations. Specifically, the study has the following objectives;

- to examine auditors' and clients' expectations and perceptions about the ability of the VfM audit to improve public sector organisations' performance;

- to examine, from both auditors' and clients' perspectives, the impact of the interplay of personal (the VfM auditors' competence relevance of skills, experience and knowledge of the public bodies' activities), interpersonal (task interdependence between the external VfM auditors and the clients) and external factors (the ambiguity of the VfM audit process) on the VfM audit performance; and

- to identify the nature of potential role conflicts in the VfM audit environment along with the causes and consequences of such potential conflicts.

The results show that the VfM audit was perceived as an important potential means with which to improve institutional performance in the public sector, but had been poorly implemented in the audited bodies. While the majority of the VfM auditors interviewed took an extremely positive view of their own achievements in terms of improving public institutions' performances and delivering VfM services, the majority of the clients that we interviewed were not convinced of their auditors' competence to carry out a VfM audit effectively, and to provide them with valuable recommendations.

Our results show that differences in expectations and perceptions of role between the external VfM auditors and the auditees give rise to significant conflict. Three types of role conflict have been identified; (a) conflict between the external VfM auditors' roles and their own professional values and standards (person-role conflict); (b) conflict between the external VfM auditors' actual capabilities and their role requirements (role overload), and (c) conflict between the external VfM auditors and the auditees (inter-sender conflict).

Finally, the paper suggests that there is a necessity for more studies to examine what makes for an effective VfM audit. Research is needed into the different contexts in which VfM audits are found and how contextual factors impact on the auditing process, especially in view of the pressures for change which characterise public sector context nowadays. 
Abstract: This paper uses both role theory and audit expectations gap theory to critically evaluate the ability of Value for Money (VfM) audit procedures to improve performance in UK public sector organisations. Our paper reports on an empirical study of seventeen auditors and twenty two representatives of VfM client organisations. The results show that although the VfM audit plays a part in enhancing the institutional performance of the public sector, much of the audit's practices have not been institutionalised in the audited bodies as had previously been assumed. Questions were raised about the relevance of the auditors' experience and knowledge of the audited body's activities. Our results also indicate significant role conflicts in the VfM process. Three types of conflict could be identified; (a) conflict between the VfM auditors' roles and their own professional values and standards (person-role conflict); (b) conflict between the VfM auditors' capabilities and their role requirements (role overload), and (c) conflict between the auditors and the auditees (intersender conflict).

Keywords: Value for Money (VfM) Audit; Audit expectations gap; Role Theory; UK Public Sector Organisations.

\section{Introduction}

The late 1970s heralded dramatic changes in the structure and management of public sector organisations in the UK, brought about by the view that they were insufficiently accountable, wasteful, and thus not giving value for money (Cooper, 2004; Prowle, 2010). This neoconservative ideological view (Cochrane, 1993; Arnaboldi and Lapsley, 2008) sought to link public agency, efficiency, and accountability through the introduction and adoption of private sector management concepts and practices. The consequence was intended to be an increased emphasis on cost control, financial transparency, the introduction of quasi-market mechanisms in contracts, and the enhancement of accountability to customers for quality of service via the creation of performance indicators (Power, 1999; Golembiewski and Kuhnert, 1994; Ghobadian et al, 2007).

In parallel, the role of external auditors within the public sector expanded from simply auditing the accounts and reporting on the regularity of the public audited bodies to a stronger focus on evaluating management performance and commenting on issues such as the economy, efficiency and effectiveness of the use of taxpayers' money (Glynn and Murphy, 
1996). As a result of this change in clients professional scope, in particular those nonaccounting professionals and managers at the operational level, started to have to engage with their commenting on auditors' work.

There is growing evidence (Koo and Sim, 1999; Tanko Samuel and Dabo, 2010) that gaps can develop between auditors' and clients' perceptions of the usefulness of the VfM audit giving rise to role conflicts (see also Glynn, 1983). It is in this theoretical tradition that the present study sits. Specifically, the aim of this study is to examine the ways in which external auditors and the auditees (mainly professionals and operational managers), perceive the performance of the practices of the Value for Money (VfM) audit in the UK public sector. Interviews were undertaken with auditors from the National Audit Office (NAO), the Audit Commission (AC), and different accounting firms operating in the private sector, all of which undertake VfM audit in public sector organisations. Clients were chosen from different organisations within the National Health Service, Local Government Authorities, Police Service and Housing Associations.

The study seeks to make two areas of contribution to knowledge. First, by using qualitative research methods and asking questions such as 'How' and 'Why', this research provides deeper insights into the practice of the VfM audits than has previously been undertaken. New insights are presented on the external VfM auditors' and their clients' expectations of the VfM auditors' roles, and how both parties perceive the usefulness of the VfM audit in terms of improving performance in UK public sector institutions. The research also provides explanations about why a gap in expectations or perceptions exists and, consequently, how such a gap affects the performance of VfM audit practices. In addition, by adopting a qualitative research approach, factors that hinder the performance of the VfM audit practices and undermine its impact on the public sector audited institutions are identified. These factors range from personal (the VfM auditors' competence, relevance of skills, experience and knowledge of the public bodies' activities), interpersonal (task interdependence between the external VfM auditors and the clients) and external factors (the ambiguity of the VfM audit process). Second, the research on audit expectations gap has focused on identifying the existence of such a gap between the auditors and different users of the financial statements concerning the duties and responsibilities that are supposed to be fulfilled by the auditors (see for example Koo and Sim 1999; Gibbins, McCracken and Salterio, 2010). However, the same literature dismissed the audited organisation's perspective. Therefore, this article provides a better understanding of the process of the VfM audit, as expected and perceived by the external auditors and the auditees (professionals and operational managers). 
The rest of this paper is organised as follows. Section two reviews the literature in the area of public sector auditing and VfM audit. Section three critiques the theoretical perspectives used in this study. Research methods and design are discussed in section four. The study results are presented and evaluated in section five. The last section concludes the paper and outlines some recommendations for policymakers and areas for future research.

\section{Literature Review}

Before the 1960s VfM audit used to refer to the type of audit which focused on assessing the economy and efficiency of government expenditures (Normanton, 1966). Since then, the field has expanded; the VFM audit (often used synonymously with performance audit) now refers to the assessment of public services in terms of economy, efficiency and effectiveness - the “3Es” (Power, 1997; Lapsley, and Pong, 2000; Morin, 2001; Funnel and Wade, 2012).

The VfM audit could be regarded as a form of 'performance auditing' (Pollitt et al., 1999, cited in Arnaboldi and Lapsley, 2008:20), a notion which most frequently applied to European countries (Pollitt, 2003), or it could be more readily understood as a form of 'comprehensive auditing', as defined in North America (Everton, 2003), or it could be essentially viewed as providing a best value audit, as has been inferred in the UK (Arnaboldi and Lapsley, 2008).

In contrast to the financial audit Barzelay (1997) argue that the VfM audit is more than a neutral monitoring technique. Auditors who are appointed to report on public organisations are expected to carry out their work not only to maintain confidence in public sector spending but also to add value by reporting on how the organisations might achieve improvement in the delivery of public services (Percy, 2001). Bowerman, Raby and Humphery (2000) note that the performance audit is an important tool, but is only one of a wide range of performance measurement and monitoring vehicles that are being used by public sector managers and officials to improve accountability and performance. In Sweden, Grönlund et al., (2011) concluded that such audits may help to assess both how the government and/or central agencies fulfil their mandates and how the government and its related agencies adhere to legislation, rules and policies (right or wrong). The authors observed that in some cases, the Swedish National Audit Office equates compliance audit with performance audit. This is an indicator of the general complexity of the requirements of such audits and the way that it can be interpreted. 
Lonsdale (2011) in his outline of the historical development of the VfM audit, from the early 1980 's through to 2009, identifies a number of changes in VfM audit methods. In the 1980s to 1990 s there was widespread use of questionnaires and surveys. Then in the early 2000 s new methods such as focus groups, case studies, international comparisons and literature review began to emerge. Recent research studies have introduced further methods in studying VfM audit including site visits, expert panels and focus groups. The context of VfM audit itself has apparently been shaped and defined by the changes in the environment in terms of administrative challenges, intellectual and technological developments. Twenty six of the methods Lonsdale identified are now used routinely, and others intermittently to suit the context. The use of such varied methods potentially means that the VfM audit can access and use rich and deep data. However, it raises the potential for misunderstanding and confusion over the content and process of the audit (Byrne and Pierce 2007; Hopper, 1980; Keating and Jablonsky, 1991; Siegel, 2000). It also implies that auditors need to have a much greater range of knowledge and skills than previously used.

Arnaboldi and Lapsley (2008) draw on Power (1997) to assess the perceptions of management in local government in Scotland, and how Best Value Audit (a version of the VfM audit) has impacted upon public sector organisations. They studied whether managers saw audit perceptions as a critical reference point in guiding their actions. They found strong evidence to support Power's views, in that respondents addressed the process of Best Value Audit as a tick-box exercise, rather than changing their behaviour as a result of the advice they received. Bowerman et al (2000) argue that the performance audit can be seen as just one element within a wide range of performance measurement and monitoring vehicles (e.g. self-assessment or inspection), which are being used by public sector managers and officials to improve accountability and performance. Morin (2001) notes that the auditors' style of leadership, their credibility in the eyes of the auditees and the connotations perceived by the auditees in the influence modes, and the use of statutory power by the auditors, are all factors that could enhance or hinder the effective performance of the VfM audit.

Research on the VfM audit's effect on performance tends to have focussed on the views of the auditors and the audit bodies concerning the auditing process (Arnaboldi and Labsley, 2008; Morin, 2008; Barrett, 2010; Funnel and Wade, 2012). The sparse literature on performance improvements shows that although the term VfM has become embedded in the day-to-day life of public organisations, its impact as a management tool for improvement performance cannot be taken for granted (Morin, 2001; Pollitt and Summa, 1997). 
In the UK, the origins of audit work covering the assessment of economy and efficiency in public sector administration dates back to World War I and the post-war crises (Normanton, 1966, p. 201). However, most of the key developments in this area took place during the 1970s following a dramatic increase in public expenditure in the UK public sector (Glynn, 1985; Pollitt, 1986; McSweeney, 1988; Heald, 2003; Pollock, Price \& Player, 2007). The Conservative Government came to power with a manifesto to improve efficiency and minimise waste in public sector expenditure. To achieve these objectives, they introduced strict financial measures accompanied by enhanced scrutiny and introduction of expanded audit mandates at both central and local government levels. These were tasked with assessing (and thereby improving) the efficiency of the public services (Glynn, 1985). The early 1980s saw the extension of the VfM audit process to cover the 3Es. Specifically, it signified the beginning of a shift in interest from the measurement of input resources, such as money and staff, to a concern in measuring the output, that is, what such input was instrumental in achieving (Glynn, Perkins \& Stewart, 1996). In 1983 the British government introduced VfM audits as part of statutory duties for the Audit Commission (AC). The AC was given the responsibility of undertaking VfM audits (carried out either in-house or sub-contracted to professional accounting firms in the private sector) of local government organisations, related bodies and operational branches of the National Health Service in England and Wales. In August 2010, however, the Secretary of State for Communities and Local Government announced that the Commission was to be scrapped, with its functions being transferred to voluntary, not-for-profit or private sector accounting firms. The new plan enables the government to save $£ 50$ million annually, with the Commission's functions transferred to the local ombudsmen and private accounting firms. Legislation to abolish the Commission was included in the Local Audit and Accountability Act 2014, with a planned closure date of 1 April 2015 (Audit Commission, 2014).

The National Audit Office (NAO) was another body established under the terms of the National Audit Act of 1983 in order to carry out VfM audits in central government (Lapsley $\&$ Pong, 2000). The act approved the expansion of the auditor's role in the UK public sector as it granted the Comptroller and Auditor General remit to carry out "examinations into the economy, efficiency and effectiveness with which departments or other defined bodies have used their resources in discharging their functions, with the proviso that he/she must not question the merit of policy objectives" (House of Commons Library Research Division, 1992: 34).Thus, the traditional focus of public sector audit on regularity has been overtaken by giving auditors responsibilities to investigate that proper arrangements are in place to 
secure VfM in the use of public resources and to enhance the financial capability of public service organisations. These focus especially on cost-saving measures arising from changes in working patterns and practices. According to Politt (2003) the main reasons for the expansion in the external auditor's role was the recognition that auditors needed to take on multiple roles and assess multiple performance indicators; assessing performance in the public sector is difficult, as it cannot be judged by a single indicator or measure (Chowdhury, Innes and Kouhy, 2005; Audit Scotland, 2010; Talbot and Wiggan, 2010).

The UK governmental ideology over the last two decades has placed further emphasis on the assessment of performance outcomes of public sector organisations and whether their resources are properly managed (Barrett, 2010; Micheli and Neely, 2010). This is evidenced by the statement by the Audit Commission (2010) that auditors are required to clearly determine in their reports if the audited bodies are properly positioned to satisfy the three parameters of performance: effectiveness (ability to manage spending and increase outputs); efficiency (ability to be productive); and economy (ability to minimise the service inputs). Consequently, VfM auditing emerged as powerful tool with which to reform public sector institutions (Lapsley and Pong, 2000; Power, 2000; Sharma, 2007; Gronlund, Svardsten and Ohman, 2011). The UK Government has adopted VfM audit as a tool to keep pressure on public organisations' management in order to achieve the maximum outcome from the public resources they are using, while simultaneously reducing public expenditure to the lowest possible level (Stewart and Walsh, 1992;Bowerman, Humphrey and Owen (2003).

The continuous developments in VfM audit led to the expansion in external auditor's role as auditors are required to take on multiple roles, which were not perfectly reconcilable with one another (Politt, 2003). In the public sector it becomes even more difficult to assess performance or output as its performance cannot be judged by a single parameter (Chowdhury, Innes \&Kouhy, 2005). Flesher and Zarzeski (2002) argue that the scope of public sector audit should go a step further than the standards and procedures that are applicable to audits of financial statements and involve other roles. Such roles should cover: (1) commenting on propriety, fairness and compliance of financial operations with laws and regulations; (2) determining whether the public organisations are managing their resources economically and efficiently; and (3) determining whether the desired results have been achieved, established objectives have been met and whether public organisations have considered the minimum cost alternatives, which might yield the desired results. 
Given that: a) the VfM audit has begun to be used, not only as a means to carry out a financial audit, but as a powerful tool with which managers, politicians, regulators and consultants can reform public sector bodies in order to improve performance and accountability (Power, 1994); b) the similarity across private and public sectors of the audit's broad aim (McCrae and Vada, 1997 and Choudhury et al., 2005); and c) the literature still lacking empirical research on the practice of the VfM audit and its impact on the audited bodies (Glynn, 1985; Guthrie and Parker, 1999; Bowerman et al, 2000; Chowdhury et al., 2005), there is a clear need for examining auditor and client expectations and perceptions of the performance of the VfM audit in public organisations. This is likely to help in identifying a potential perception performance gap between the two parties.

All the study's participants, both auditors and clients, have been involved in the VfM audit for many years. The auditors enjoy high profile positions in their respective organisations (NAO, $\mathrm{AC}$ and private accounting firms) with extensive experience in VfM audits of public organisations. The majority of clients are also heads of financial and performance departments.

Qualitative cluster analysis was used to examine the interview data. Based on this method themes emerging from the data were aggregated in line with the study's aims and objectives. In total four major areas could be identified in the data, which were also categorised based on the organisation type and role of the interviewee in the audit process (details about the interviews and data analysis procedures are provided in the research methodology and design section).

Based on this analysis, we argue that different perceptions exist between auditors and auditees on the purpose and usefulness of the current VFM audit process and practice. Auditees consider receiving less value from the recommendations of auditors, which do not result in an improvement in audited bodies' performance. Specifically, the paper explores the expectations' gap between auditors and auditees and the factors contributing to the gap.

\section{Theoretical Framework of the Study}

Kahn et al (1964) and Katz and Kahn (1978) introduced role theory to explain how people in organisations enact their roles, and what influence those roles. Their theory models how individual characteristics and relationships affect the roles enacted by the focal person. These expectations are sent to the focal person by the role sender, or in some cases more than one 
role sender. In this case the role senders are termed the role set (Merton, 1957). The theory says that the focal person behaves according to the expectations sent by the role set and that his or her interpretation of these expectations would influence the way that the role is enacted. Biddle (1979: 132) defines expectations as 'subject held or emitted statements' by a person. These statements are reactions to specific object characteristics. Biddle differentiates expectations according to the person who holds or receives them, their initial source, nature or shape. The role played by the focal person as a result of his interpretation is referred to as received role; the interaction between the role set and focal role occupant is referred to as the role episode.

Under role theory organisational characteristics such as its culture, structure or size, have direct influence on role sender(s) expectations of the focal role person (Lynch, 2007; Wickhamand Parker, 2007). Interpersonal factors such as the nature of the relationship between the role sender and the focal role person also affect the expectations of the role sender. The interpretations and behaviour of the focal role person is influenced by personal, organisational and relationship-related factors. The focal role person enacts the role(s) with the aim of managing a specific situation(s), both the situation and the person's behaviour being governed by context-specific rules. The term role is defined as a group of tasks that the focal role occupant accepts to carry out (Michael, 2001; Liu, Gould, Rollins and Gao, 2014). This role can be influenced by individual attitude, skills and competences and other interpersonal factors. It is the variations in expectations and the type of situation in which the role is enacted that sometimes results in role incompatibility between the role sender and the focal role person (Appah and Oyadongham, 2011).

Failure to meet the expectations of the role sender results in what is called role conflict while the experiencing of uncertainty vis-à-vis expectations contributes to role ambiguity. Wolfe and Snoek (1962) and Van Sell, Brief and Schuler(1981) note that role conflict is the outcome of a number of pressures, which makes the focal person unable to comply with the role sender(s) expectations. Role conflict influences the successful completion of tasks, especially those that are linked to one another. Ambiguity instead is caused by the focal person's unawareness of what he is supposed to accomplish (Katz and Kahn, 1978): incomplete information makes the focal person unable to perform as expected by the role sender(s). This situation occurs when the focal person has a lack of understanding of the sender(s) expectations or when he does not know how to fulfil these expectations. 
In the context of the VfM audit, there is increasing consensus among scholars that the VfM audit involves considerable interaction between auditors and auditees (Gendron, Cooper and Townley, 2007). Such interaction may take different forms such as persuasion, dissuasion, advice and warning (Morin, 2003). For this micro political process, a considerable degree of agreement over means, goals and ends has to be negotiated. Those working within a micro political traditional (see for example Power, 2000) have suggested that some of the apparent lack of success of VfM audits in improving organisational performance may be to do with a mismatch between the expectations and ambitions of the client and those of the auditor (Byrne and Pierce 2007; Hopper, 1980; Keating and Jablonsky, 1991; Siegel, 2000).

As outlined in the literature review section VfM audit is created to achieve particular goals, such as improving accountability and performance through delivering VfM services. The expectations that underlie these mean that it is necessary to establish particular relationships between auditors and auditees (professionals and operational managers). The process of VfM audit also implies an interaction between the auditors and their clients that constitutes an attempt by the auditors to influence their clients both to make real change in the way they manage public resources and to improve performance (Morin, 2001).

Auditors come to the VfM audit with expectations and preferences about what their clients should do or avoid doing to deliver VfM services. These auditors' expectations come mainly from the VfM audit regulatory bodies' guidelines (Sharma, 2007), but also from the auditors' own professional training and their experience in VfM audit (Lapsley and Pong, 2000; Funnel and Wade, 2012). Based on these expectations, VfM auditors undertake the audit and communicate their expectations to their clients in an attempt to influence the way in which taxpayers' money is managed. These communications normally take the form of recommendations that are intended for either complete or partial implementation by the auditors' clients.

Clients also have expectations of the VfM auditors. These might be about the auditors' assessment of VfM factors (economy, efficiency and effectiveness), the ability to make a competent assessment, the practicality and relevance of their recommendations or the usefulness of the whole VfM audit process in improving performance in their institutions. Hence, it seems likely that the clients are not always passive recipients of auditor expectations. Instead, they might try to modify these expectations through a process of negotiation with their auditors to bring about conformity between the two parties' expectations (Stone-Romero, Stone and Salas, 2003). These processes of negotiation are more likely to narrow, or even eliminate, a potential audit expectations and perception gap 
between the external VfM auditors and the auditees. These negotiation processes are influenced by the interplay of social factors at the personal (the VfM auditors' competence based on their relevant skills, experience and knowledge of the Public bodies' activities), interpersonal (task interdependence between the external VfM auditors and the auditees) and external levels (the ambiguity of the VfM audit process), in the VfM audit environment.

Role conflicts, as mentioned above, form another element of role theory, which may also help in identifying potential role conflicts in the VfM audit environment. For the context of this study it has been conceptualised that both the VfM auditors and their clients have expectations and preferences in regard to one another. These expectations may have a significant impact on the VfM audit, since an audit expectations gap is likely to exist and give rise to role conflicts. Morin (2003) posits that controlling performance and improving it are two important objectives of the VfM auditors, but these objectives might conflict with each other. Morin argued that, if auditors involve themselves in helping the audited bodies to improve performance, this might risk their ability to maintain full and transparent control, or accountability, to the wider public. Morin also found that recommendations aiming to improve efficiency might prevent the achievement of effective objectives. For further literature on VfM and audit expectation gap please see Appendix I.

According to the role theory the following types of conflicts might apply to VfM audit situations: (1) conflict between VfM auditors' roles and their own values and standards (person-role conflict); (2) conflict between the VfM auditors' capabilities and their role requirements (role-overload conflict); and (3) conflict between VfM auditors and auditees (inter-sender conflict). In this study each conflict is examined thoroughly within the framework of role theory.

\section{Research Methodology and Design}

The assessment of VfM audit quality is a subjective one, due to the lack of standardised criteria of what makes for good practice, on both the auditor and client side, coupled with variations in perception of its usefulness on the part of the actors involved in the process. A qualitative, explanatory, study was therefore deemed appropriate since it allowed for the interpretation of participants' perceptions (Cassell and Symon, 1994). Semi-structured interviews of both auditors and auditees were chosen as the data collection method. The literature suggested a number of pertinent themes that needed to be covered in all the interviews (Drever, 1995). The core questions related to the interviewees' perceptions of the 
practices and effectiveness of the VfM audit (see the Appendix II for details about the interview's questions plan). Other questions related to specific organisational contexts or to the role of the interviewee.

The auditors that were interviewed included those working for the NAO and AC, as well as private accounting firms who were carrying out VfM audits in public sector bodies. Client interviewees represent four public organisations: (1) the National Health Service (NHS); (2) Local Government Authorities; (3) the Police Authority; and (4) Housing Associations. The breakdown of organisations approached in the first place is: 8 from NHS; 8 from Local government Authorities; 10 from the Police Authority; and 12 Housing Associations. Organisations that ultimately cooperated are: 6 from NHS; 5 from Local Government Authorities; 5 from the Police Authority; and 6 Housing Associations. Clients from central government were omitted because of access difficulty.

A total of thirty-nine participants were interviewed. The auditor group comprised 17 interviewees, all of whom had wide experience in the area of VfM audit, and had worked with a number of different public bodies. The client group comprised 22 interviewees, all of whom were in senior management positions.

The selection of the client organisations was based on the desire to seek a diverse group of respondents. Diversity related to the professions working in the client organisations, and also the diversity of the services the organisations deliver to the public. This was considered important since VfM auditors may place more emphasis on efficiency in some organisations, and an emphasis on high quality in others, particularly when these services relate to public health or safety. Hence, VfM auditors' assessments may depend partly on the type of client they were interacting with, as well as the type of service provided.

Another criterion used to select the client organisations was the length of time that they had been subject to VfM audit. The longer the time they had been involved in VfM audits, the better their likely understanding of the roles and responsibilities of the VfM auditors and the greater the extent to which these auditors would be able to fulfil their role satisfactorily. Experience is likely to influence the development of an audit expectations gap between VfM auditors and the auditees.

The interviews were recorded and transcribed. The data were first grouped according to the main sectors involved, which enabled cross analysis between the various groups. During the process of categorisation, text was clustered in themes, then arranged and rearranged, and eventually a category could be defined. A total of four meta categories were formed. These were: a) participant expectations of the roles and responsibilities of the VfM auditors; b) 
participants' perceptions of the performance of VfM audit; c) participants' perceptions of potential role conflicts; and d) participant perceptions of how social factors might affect the VfM audit's impact on audited bodies. These four categories could be further sub-divided. For example category b) had several sub-categories including participants' perceptions of the VfM auditors' competence, the materiality of the VfM auditors' findings, the accuracy and fairness of their reports, and whether the process of VfM audit was perceived as a controlling or an improving process. Category c) was divided into three subcategories, conflict between VfM auditors' roles and their own values and standards, conflict between the VfM auditors' capabilities and their role requirements, and conflict between VfM auditors and clients' expectations of the other's role. These categories formed the basis for the results presented in the next section.

\section{Results and Discussion}

In this section we discuss our interviewees' perceptions of the VfM auditors' roles and the VfM audit's ability to improve the performance of UK public sector organisations. We also examine the different role conflicts arising between auditors and auditees, both in terms of causes and consequences, based on the VfM audit practice.

VfM auditors exercise roles which are intended to directly affect their clients' behaviour by identifying what they believe to be the strengths and weaknesses in the client's line of activities and in so doing help them to improve their performance. Our data show that both parties hold differing expectations of one another and different perceptions as to how effective the process is - there is a gap in both expectations and outcomes. Auditors have expectations of the clients in terms of the way they handle public resources and deliver services. Clients have expectations of the auditor's role and the usefulness of the VfM audit; auditors are expected to provide recommendations that their clients find valuable. If auditors do not fulfil these expectations, clients will ignore their recommendations and have little confidence in the auditor's findings.

Hence, both parties should conform to the expectations of one another. If perceptions are congruent with each other then this might be considered as a positive indicator of the impact of VfM audit in improving the audited organisations' performance. However, when there is little or no consistency between the two parties' perceptions and expectations an audit expectation gap is likely to develop. 


\section{Expectations of the VfM audit}

Interviewees were asked to give their views on the VfM audit process and its effectiveness. Our data indicate a consensus among the auditors on their roles in the VfM audit. Their responsibilities are to assess client performance through an evaluation of the 3Es, measuring these against a set of performance indicators provided by the public sector audit regulatory bodies. In their report's concluding remarks, they must say whether or not they are satisfied with the audited body's ability to deliver VfM outputs, such conclusions being based on congruence or disparity between the benchmarks and clients' actual practice. Areas for improvement must then be identified by the auditors, alongside recommendations to achieve such improvement. The auditors' pivotal role being that of expressing judgment, through their reports, about the adequacy of audited bodies' arrangements to secure economic, efficient and effective use of public resources.

Porter (1993) classifies audit expectation gaps into two types, i.e. reasonableness gap and performance gap. He argues that reasonableness gap may exists if the auditors' clients have unreasonable expectations of the auditors' roles which differ from the roles defined by the law and professional promulgations and if the auditors themselves do not recognise that the expectations form part of their roles. While, performance gap could be defined as the gap between what society can reasonably expect the auditors to accomplish and what they are perceived to achieve (ibid: 50).

Based on Porter's (1993) definition of audit expectations gaps, our data indicate no significant audit expectations gap between auditors and clients regarding their ability to assess the 3Es benchmarks. There was a general agreement between both parties about the auditors' ability to assess these factors. However, there was an expectations gap in terms of the recommendations made. Although VfM auditors agreed that they considered the extent to which they could provide clients with practical guidance to rectify a specific problem and improve performance, they also argued that they could not interfere directly in the client's method of tackling problems. Instead the auditors said they would encourage their clients either to consult another organization that had faced similar problems, or use information published by the regulatory body, such as the Audit Commission.

Clients, on the other hand, expected their auditors to not only assess areas where performance could be improved, but also expected their VfM auditors to carry out a deep investigation and provide them with concrete suggestions about how to remedy problems and improve performance: what emerges is the existence of a 'reasonableness' gap between auditors and 
clients. This was particularly the case of respondents from the police authorities and housing associations. Part of this was frustration that the auditors were professionals with a wide perspective and practical experience of different organisations in the public sector and, yet, despite, this rich and extremely useful information, could not share good practice and bring some of their own learning into the organisation they were auditing. Without this, the audit risked becoming irrelevant.

Auditors in contrast all said that client expectations of this were unreasonable, and insisted that undertaking such activities would compromise their independence and ability to work freely and objectively (Morin, 2003). Mindful of their official VfM audit remit (see section 22, Code of Audit Practice, 2005) all interviewed auditors argued that their VfM audit role could and should not include providing their clients with what they deemed to be consultancy services: there was the potential for conflict between i) suggesting solutions and ii) assessing their implementation.

\section{Expectations concerning the outcomes of the VfM audit}

This section focuses on the application of the VfM audit and its ability to improve UK public sector performance. Three concepts (auditor competence, audit evidence, and performance audit) emerged as important from our data.

\section{VfM auditors' competence}

The majority of auditors interviewed claimed that they were competent at undertaking the VfM audit and providing their clients with recommendations that would help them to improve performance. Those that did not claim to be competent appeared to be the result of differences between the VfM audit and financial or commercial audits (Power, 1997): competence in one type of audit was no guarantee that the auditor felt competent at undertaking any other type of audit. Consistent with Pendlebury and Shereim (1990), the National Audit Office (NAO) auditors judged themselves to be the most able to assess client performance, while auditors from the Audit Commissions and private accounting firms had slightly more reservations in this regard. The latter accepted that specialists and managers in the services department they were auditing were better able to judge their own organisation's performance. Whereas $85 \%$ of the auditors from private accounting firms said that they were competent to assess organizational economy and efficiency, only $46 \%$ were convinced that they were competent to assess effectiveness. The variation in responses between Audit 
Commission and NAO participants is driven by the fact that the NAO is a big organisation with access to all Central Government departments and which chiefly examines, on behalf of Parliament, issues pertaining to public departments' expenditure of public resources and thus, their delivery of VfM services. The NAO also carries VfM studies on a national scale -much larger than the studies carried out by other audit bodies.

However, although most of the auditors perceived that they were competent at undertaking a VfM audit, most of the client respondents emphatically took the opposite view. The main discrepancies occurred in relation to perceptions about a) the auditor's understanding of the nature of the client organisation's objectives and the services provided, and b) the auditor's ability to assess effective performance. Only $60 \%$ of the Police Authority and $33 \%$ of the NHS bodies perceived that the VfM auditors had relevant skills and experience, and a sufficient understanding of their operations.

In light of these variations, our results suggest that unlike the private sector businesses where outcomes can be judged mainly on the sole criteria of 'profitability', the outcomes of the public sector organisations need to address the social and emotional needs of the public. Economy and efficiency can be assessed on quantitative measures. To assess economy, auditors examine the cost of public resource acquisitions, while efficiency is assessed by comparing inputs with outputs (e.g. comparing the number of doctors in a hospital ward with the number of patients that have been treated in that ward). Effectiveness, however, is more difficult to assess, since auditors must consider output quality, as well as considering whether the audited bodies have achieved those objectives for which the public's funds have been used. All elements must be considered simultaneously in order to evaluate the audited bodies' delivery of VfM services. From this it may be assumed that auditors need particular skills, (e.g. skills to assess the quality of public services) as well as sufficient public sector experience to be able to balance these three elements in their assessment. Not only must auditors possess skills and expertise vastly, different from those needed to undertake a purely financially-based audit, they must also understand, to a considerable degree, the nature of public sector activities.

Our analysis reveals that there are tangible and intangible values within the public sector profession. The tangible values are explicit and can thus be encapsulated and understood by the external auditors who are looking at things from a business point of view and base their judgments on 'hard evidence'. However, there are also undeniable, intangible and implicit values which, being emotionally-related, are important to the public regardless of cost. These values, including the emotional interests of the patients, their need for care, and the public 
need to feel safe, could never be captured by looking at hard evidence. The auditees argued that such values are far more difficult to be understood by auditors who are mainly trained as accountants to consider things from a purely financial viewpoint. They also add that this lack of understanding particularly in relation to intangible values will be reflected in auditor assessment of effectiveness.

\section{VfM Audit and Power Asymmetry}

Most of the auditees interviewed thought that the in-house auditors from the NAO and the Audit Commission had more relevant technical skills and knowledge of the public bodies' activities when compared to their counterparts from the private accounting firms, as they had worked as professionals in the public sector organisations prior to commencing their careers as VfM auditors. The external VfM auditors from private accounting firms, typically have obtained their knowledge through gaining accountancy qualifications and experience in financial audits. This knowledge however, was not perceived by the auditees to be sufficient to make them experts in VfM auditing.

Consistent with Peiró and Meliá (2003), this knowledge power asymmetry, when combined with the intrinsic ambiguity of the client environment and the auditor's role, meant that in most cases external VfM auditors' performance was not seen to have reached a sufficient level of influence over the audited bodies to ensure that they adopted the auditors' recommendations. As a result, little real change in the way the audited bodies managed public resources was achieved. This view was shared by the auditors and auditees alike.

It is relatively easy for auditors, when carrying out a financial audit, to challenge their clients if there is any misconduct in the financial statements. However, in the VfM audit, the audited bodies have to provide the external auditors with evidence about their conduct and reasons for any overspend in their departments. Subsequently, the external auditors must make a professionally-informed assessment of the evidence provided by the audited bodies, and make recommendations on how to improve their performance. Our data show that this is extremely difficult to do, and to establish facts or culpability when they have disputes with the auditees over the conduct of the VfM audit process.

The VfM audit overload in the UK public sector (Pendlebury and Shreim, 1990), which also being identified in this study, intensifies the impact of interpersonal factors on the external VfM auditors' powers and their ability to influence their clients. Our data revealed that, because of this audit overload, the external VfM auditors do not have enough time to examine 
each individual department in the audited bodies to identify precisely where problems lie. Thus the auditors can only make a general overview, based on the selected evidence provided by the auditees, of the audited body's VfM status. This general overview is insufficient to convince the auditees of the reliability of the auditor's findings and on the value to be added through the adoption of their recommendations. Thus, one of the most important determinants of the power of external VfM auditors over their clients is critically undermined. Given this context, the audit outcome would be improved if the audited bodies could identify those sections that are overspending or not achieving their objectives, and provide the auditors with reliable evidence with which to do a focussed piece of work on these specific departments.

\section{Role Conflicts}

Role conflict occurs when there is incompatibility or disagreement between an auditor's tasks, resources, rules or policies, and those of an organisation (Dale and Fox, 2008). Our data show that an audit expectations and perceptions gaps in the VfM audit environment gave rise to role conflicts. In total, three types of role conflict could be identified: role overload conflict, person-role-conflict and inter-sender conflict.

First, conflict between the external VfM auditors' capabilities and their roles leads to role overload conflict. This had three main reasons: a) the auditees perceived that the auditors' have lack of competence to carry out the VfM audit and provide the clients with useful recommendations, b) the high volumes of VfM audit driven by the size of the organisation (i.e. audit overload) combined with limited clients' budgets allocated by the auditees for the audit process, and c) high levels of ambiguity associated with the VfM concept itself, due to the different possible meanings of the term 'Value for Money' and the inherent intangibility and ephemerality of public services.

Second, role-overload results in a gap between the VfM audit requirements and external auditors' values and professional standards. This is a person-role-conflict, which occurs when the expectations associated with the auditor's moral or ethical self-concept are not met due to the incompatibility of professional inclinations and commitments to the audited bodies by the auditors (Asiri, 1998). The professional commitment of the auditors to their financial audit clients is to provide them with a good quality audit for the purpose of improving the credibility of their accounts in the eyes of the users of the financial statements (Baotham and Ussahawanitchakit, 2009). This commitment to the clients could be fulfilled by auditors in the course of carrying out their audit function via the process of preventing, detecting and 
reporting any uncertainties to the relevant users (DeAngelo, 1981; Moizer, 1985; and Porter et al., 1996).

A similar stance ought to be true in the case of the VfM audit, since the main aim of the auditors is to provide the audited bodies with a reasonable assessment of their performance and assure the government and the public, at large, of their proper conduct. Yet our interview data unveil that due to time constraints, budgetary limitations and lack of the auditors' competency, the ability of the external VfM auditors to make a good quality assessment and provide their clients with useful findings is a matter for concern. Auditors did not believe that they should be providing consultancy services, an important role identified by the auditees, as it conflicts with their professional stance (Assiri, 1998).

The third gap, inter-sender conflict, which occurs when a role sender requires a role receiver to perform contradictory or inconsistent roles, emerged from the practical difficulties of determining the best practice in the VfM audit. Our findings suggest that these practical difficulties stem from the absence of standards upon which to draw evidence as to whether or not public services provide good value for money. These difficulties give rise to conflicting perspectives on the appropriate measures to use to assess areas for improvement. Attempting to apply standardised performance indicators by the external VfM auditors to the public sector bodies created inter-sender conflict as the auditors applied roles which have been set up by the regulatory bodies to be applied across public sector organisations, and which the clients did not accept were appropriate. These clients were also critical of the inflexibility of the process and the inability of the auditors to adapt standardised roles to the specific circumstances of their organisations. The auditee group suggested that they would normally use different ways of managing public resources to the ones that the auditors were familiar with, or would develop specific policies and practices in collaboration with their service users.

\section{Conclusion}

The data presented in this study indicate that both auditors and auditees perceive that the VfM audit is a potentially important tool with which to improve institutional performance in the public sector. But both groups indicate that the VfM audit is not yet as effective as it should be. Our interview data reveal clear differences in expectations and perceptions between the external auditors and their clients about the auditors' roles and the performance of the VfM audit. Clients expect the VfM auditors to identify areas where their performance needs to be improved, suggest solutions and then help to implement solutions. Our results, 
consistent with Morin (2003), revealed that almost all the auditors perceived such client aspirations fell outside the remit of their role, and that such expectations could compromise their professional independence and objectivity.

In addition, the study findings show that, while the majority of the auditors interviewed took an extremely positive view of their own achievements in terms of improving public institutions' performance and delivering VfM services, the majority of the clients, and some of the auditors, were not convinced of their competence to carry out the VfM audit effectively and provide appropriate recommendations. As a result, few auditees felt that there had been improvements in the way they managed public resources as a result of the auditors' efforts. Personal factors such as the VfM auditors' competence, skills, experience and knowledge of the public bodies' activities, interpersonal factors such as task interdependence and contextual factors such as the ambiguity of the VfM audit process, all had negative effects on the ability of the external VfM auditors to influence the audited bodies.

Moreover, our results show that audit expectation and perception gaps between the external VfM auditors and their clients give rise to significant role conflicts. Three types of role conflicts have been identified; (a) conflict between the external VfM auditors' roles and their own professional values and standards (person-role conflict); (b) conflict between the external VfM auditors' actual capabilities and their role requirements (role overload), and (c) conflict between the external VfM auditors and their clients (inter-sender conflict). These three types of role conflict were compounded by the differences in expectations and perceptions between the external VfM auditors and their clients leading to lack of respect and antipathy for the auditor and the audit process.

However, in contrast to Power (1994a), who was sceptical about the possible social benefit of investment in audit services and to Morin's (2003) study, which revealed that the role of controller for VfM auditors is more important than the role of improver, our auditees are convinced that there is a role for the VfM audit in improving performance. Respondents who supported VfM audit argued that, although the VfM audit did not, from an operational standpoint, make any special and visible contribution to public sector performance improvement, it was still able to make an invisible contribution to improved performance. The respondents are still in favour of investing in the VfM audit process, but with a continual review by the regulatory bodies. When asked about the VfM's contribution, a common response was that VfM has become more prominent and encouraged the audited bodies' management to see auditors' recommendations as a key part of their performance review. The 
majority of client interviewees added that VfM audit has brought a considerable challenge and become embedded in their organisational overall objectives to the extent the organisation's members, particularly at the management level, started to think more widely about their strategies, their objectives and the available options for the delivery of VfM services. Interviewee comments indicate three main reasons for the VfM's potential in this regard. First, the VfM audit provides audited bodies with some assurance of efficient and effective conduct. Second, when auditors indicate areas for improvement, client action to remedy is triggered; it gives senior management explicit evidence of the whole organisation's performance; and since auditors have insight into other organisations' management and delivery of public services, they are likely to bring both an external, independent perspective, and considerable practical experience. Clients may thus assess their own performance in relation to other organisations. Third, respondents who were in favour of the VfM audit argued that in some organisations, particularly in the local government authorities where elections are usually held every year, it is common for these bodies to have short-term objectives which are likely to be politically motivated. Auditors have helped them to realise the importance of having medium and long term objectives.

Our findings suggest that there is a pressing need for more studies to examine the factors that influence the effectiveness of the VfM audit. The views presented by auditors and auditees in this study have raised awareness of better methods to enhance cost-effectiveness and to improve the quality of services offered. The VfM audit's status as an appropriate tool initiates from the fact that an independent body's assessment of a public body's activities, is a good way to achieve best practice in the delivery of public services and transferability of examples of best practice across public bodies. However, our analysis also reveals that public sector organisations are continually changing their ways of managing public resources to improve the delivery of VfM services. Hence, in order for the VfM audit to be relevant and adequate in the face of such changes, its roles need to be reviewed and modified continuously.

However, most clients argued that for auditors to demonstrate real commitment to improve the VfM audit's image in the eyes of the clients the auditors themselves need to improve in fulfilling the roles they are applying. Clients argued that auditors need to familiarise themselves more with the nature of the audited bodies' business and recognise the difference between assessing the performance in private sector organisation, where the main target is to get the most possible profit, and in public organisations where the main objectives are to deliver VfM services and improve public satisfaction. Thus further research could examine the skills needed by VfM auditors, the contingent needs of the different types of public 
organisations, especially in view of the constant change which characterises the public sector organisations, and the impact of different types of skills and knowledge on the VfM audit process.

\section{References:}

Appah, E. and Oyadonghan J. K. (2011) 'Role theory and the concept of audit expectation gap in south-south, Nigeria', Research Journal of Social Sciences, Vol. 3, No. 6, pp. 445-452. Arnaboldi, M. and Lapsley, I. (2008) 'Making management auditable: the implementation of best value in local government', ABACUS, Vol. 44, No. 1, pp. 22-47.

Assiri, S. M. (1998) An understanding of internal auditors' roles as perceived by internal auditors and their clients. (UK: PhD Theses, Essex University).

Audit Commission (2005) Code of Audit Practice 2005 - for Local NHS bodies, section - 25, viewed 20 December 2008, 〈http://www.audit-commission.gov.uk>.

Audit Commission (2010) The Future of Local Audit: Issues for Consideration, viewed 25 October $2010<$ http://www.audit-commission.gov.uk $>$.

Audit Commission (2014) The Future of Local Audit; viewed 7 March 2014

<http://www.audit-commission.gov.uk $>$.

Audit Scotland (2010) Audit Scotland Annual Report 2009/10, viewed 18 October 2010, <http://audit-scotland.gov.uk/docs/corp/2010/as_annual_report_0910.pdf >

Bamber, E. M., Snowball, D. and Tubbs, R. M. (1989) 'Audit structure and itsrelation to role conflict and role ambiguity: an empirical investigation', TheAccounting Review, Vol. 14, No. 2, pp. 285-299.

Bame-Aldred, C. W and Kida, T. (2007) 'A comparison of auditor and client initial negotiation positions and tactics', Accounting, Organizations and Society, Vol. 32, pp. 497511.

Baotham, S. and Ussahawanitchakit, P. (2009) 'Audit independence, quality, and credibility: effects on reputation and sustainable success of CPAs in Thailand', International Journal of Business Research, Vol. 9, No. 1, pp. 1-25. 
Barrett AO, P. (2010) 'Performance auditing - what value?' Public Money and Management, Vol. 30, No. 5, pp. 271-278.

Barzelay, M. (1997) 'Central audit institutions and performance auditing: a comparative analysis of organizational strategies in the OECD', An International Journal of Policy, Administration and Institutions, Governance, Vol. 10, No. 3, pp. 235-260.

Biddle, B. J. (1979) Role Theory: Expectations, Identities and Behaviors, New York: Academic Press.

Bowerman, M. Raby, H. and Humphrey, C. (2000) 'In search of the audit society: some evidence from health care, police and schools', International Journal of Auditing, Vol. 4, No. 1, pp. 71-100.

Bowerman, M, Humphrey, C. and Owen, D. (2003) 'Struggling for supremacy: The case of UK public audit institutions', Critical Perspectives on Accounting, Vol. 14, No. 11, pp.1-22. Byrne S, Pierce B. 2007 'Towards a more comprehensive understanding of the roles of management accountants'. European Accounting Review, Vol. 16, No. 3, pp. 469-498.

Cassell C. and Symon G. (1994) 'Qualitative methods in organisational research', a practical guide (California: Sage Inc).

Chowdhury R. R., Innes, J. and Kouhy, R. (2005) 'The public sector audit expectations gap in Bangladesh', Managerial Auditing Journal, Vol. 20, No. 8, pp. 893-908.

Cochrane, A. (1993) 'From financial control to strategic management: the changing faces of accountability in British Local Government', Accounting, Auditing and Accountability, Vol. 6, No. 2, pp. 30-51.

Cooper, D. (2004) 'Organisational change: from Public to Private Sector, A UK based Reflective Case Study', The Journal of American Academy of Business, Vol. 5, No. 1/2, pp. 474-480.

Currie, G., \& Procter, S. J. (2005) 'The antecedents of middle managers' strategic contribution: the case of a professional bureaucracy'. Journal Of Management Studies, Vol. 42, No. 7, pp. 1325-1356.

Dale, J. and Fox, M. (2008)'Leadership Style and Organizational Commitment: Mediating Effect of Role Stress', Journal of Managerial Issues, Vol. 20, No. 1, pp. 109-130.

DeAngelo, L. E. (1981) 'Auditor independence, low balling and disclosure regulation, Journal of Accounting and Economics, Vol. 3, pp. 113-127.

Drever, E. (1995) Using semi-structured interviews in small-scale research: a teacher's guide. (Edinburgh: Scottish Council for Research in Education). 
Flesher, D. L. and Zarzeski, M. T. (2002) 'The roots of operational (value for money) auditing in English speaking countries'. Accounting and Business Research, Vol. 32, No. 2, pp. 93-104.

Funnel, W., and Wade, M., (2012) 'Negotiating the credibility of performance auditing', Critical Perspectives on Accounting, Vol. 23, pp. 434-450.

Gendron, Y., Cooper, D. J. and Townley, B. (2007) 'The Construction of auditing expertise in measuring government performance', Accounting, Organizations and Society, Vol. 32, pp. 101-129.

Ghobadian, A., Gallear, D., Viney, H., and O Regan, N. (2007) 'Public sector performance improvement through private sector management practices: a satisfactory solution?', International Journal of Business Performance Management, Vol. 9, No. 4, pp. 363-379.

Gibbins, M., McCracken, S. and Salterio, S. E. (2010) 'The auditor's strategy selection for negotiation with management: flexibility of initial accounting position and nature of relationship', Accounting, Organizations and Society, Vol. 35, pp. 579-595.

Glynn, J. J. (1983) 'Effectiveness auditing - its role in the public sector', Accountancy, Vol. 94, No. 1075, pp. 135-136.

Glynn, J. J. (1985) 'Value for money auditing - an international review and comparison', Financial Accountability and Management, Vol. 1, No. 2, pp. 113-128.

Glynn, J. J. and Murphy, M. P. (1996) 'Public management: failing accountabilities and failing performance review', International Journal of Public Sector Management, Vol. 9, No. 5-6, pp. 125-137.

Glynn, J. J., Perkins, D. A., and Stewart S.B. (1996) Achieving value for money in the NHS. (London: Saunders).

Golembiewski, R. T. and Kuhnert, K. W. (1994) 'Barnard on authority and zones of indifference: towards perspectives on the decline of managerialism', International Journal of Public Administration, Vol. 17, No. 6, pp. 595-615.

Grönlund, A., Svärdsten, F. and Öhman, P. (2011) 'Value for money and the rule of law: the (new) performance audit in Sweden', International Journal of Public Sector Management, Vol. 24,No. 2, pp. 107-121.

Guthrie, J. E. and Parker, L. D. (1999) 'A quarter of a century of performance auditing in the Australian federal public sector: A malleable masque'. ABACUS, 35(3), pp. 302-332.

Heald, D . A. (2003) 'Fiscal transparency: concepts, measurement and UK practice', Public Administration, Vol. 81, No. 4, pp. 723 - 59. 
Hopper, T. M. (1980) 'Role conflicts of management accountants and their position within organisation structures', Accounting, Organizations and Society, Vol. 5, No. 4, pp. 401-411. House of Commons Library Research Division (1992) Select committee's background paper, No. 298, $7^{\text {th }}$ September 1992 (London: HMSO).

Jones, P. and Bates, J. (1990) Public sector audit: practical techniques for an integrated approach. (London: Chapman and Hall).

Kahn, R. L., Wolfe, D. M., Quinn, R. P., Snoek, J. O. and Rosenthal, R. A. (1964) Organizational Stress: Studies in Role Conflict and Ambiguity, New York: JohnWiley and Sons.

Keating, P. J. and Jablonsky, S. F. (1990) Changing Roles of Financial Management: Close to the Business. (New Jersey: Financial Executives Research Foundation).

Koo, C. M. and Sim, H. S. (1999) (1999) 'On the role conflict of auditors in Korea', Accounting, Auditing \& Accountability Journal, Vol. 12, No. 2, pp.206-219

Lapsley, I. and Pong, C. (2000) 'Modernization versus problematization: value for money audit in public services, European Accounting Review, Vol. 9, No. 4, pp. 541-567.

Liu, A. H., Gould, A. N., Rollins, M. and Gao, H. (2014)'Role conflict and ambiguity confronting transnational business networkers: contrasting social stigma and relational risks for Chinese and Western boundary spanners', International Marketing Management, Article in Press.

Lonsdale, J. (2011) Performance auditing: contributing to accountability in democratic government. (Cambridge: Edward Elgar Publishing).

Lynch, K.D. (2007) 'Modeling role enactment: linking role theory and social cognition', Journal of the Theory of Social Behaviour, Vol. 34, No. 4, pp. 379-399.

McCracken, S., Salterio, S. E. and Gibbins, M. (2008) 'Auditor-client management relationships and roles in negotiating financial reporting', Accounting, Organizations and Society, Vol. 33, pp. 362-383.

McCrae, M. and Vada, H. (1997) 'Performance audit scope and the independence of the Australian Commonwealth Auditor-General'. Financial Accountability and Management, Vol. 13, No. 3, pp. 203-223.

McSweeney, B. (1988) 'Accounting for the Audit Commission', The Political Quarterly, Vol. 59, No. 1, pp. 28-43.

Merton, R. K. (1957) Social Theory and Social Structures, Rev. Ed., New York: Free Press. Michael, A., 2001. Human Resources Management Practice. Kogan Page Ltd., London. 
Micheli, P. and Neely, A. (2010) 'Performance measurement in the public sector in England: searching for the golden thread', Public Administration Review, Vol. 70, No. 4, pp. 591-600. Moizer, P. (1985) 'Independence', in D. Kent, M. Sherer and S. Turley, (Eds)Current issues in auditing, pp. 33-44 (London: Harper and Row Publishers).

Morin, D. (2001) 'Influence of value for money Audit on public administrations: looking beyond appearances', Financial Accountability and Management, Vol. 17, No. 2, pp. 99-117. Morin, D. (2003) 'Controllers or catalysts for change and improvement: would the real value for money auditors please stand up?' Managerial Auditing Journal, Vol. 18, No. 1, pp. 19-30. Morin, D. (2008) 'Auditors general's universe revisited: an exploratory study of the influence they exert on public administration through their value for money audits', Managerial Auditing Journal, Vol. 23, No. 7, pp. 697-720.

National Audit Office (2006) National Audit Office Annual Report 2006, viewed 15 October 2010. <http://www.nao.org.uk>.

Normanton, E. L. (1966) The accountability and audit of governments. (Manchester: Manchester University Press).

Peiró, J. M. and Meliá, J. L. (2003) 'Formal and informal interpersonal power in organisations: testing a bifactorial model of power in role-sets', Applied Psychology: An International Review, Vol. 52. No. 1, pp. 14-35.

Pendlebury, M. and Shereim, O. (1990) 'UK auditors' attitudes to effectiveness auditing', Financial accountability and Management, Vol. 6, No. 3, pp. 177-189.

Percy, I. (2001) 'The best value agenda for auditing (in the public sector)', Financial Accountability \& Management, Vol. 17, No. 4, pp.351-361

Pfeffer, J. (1981) Power in organisation. (Marshfield: Pitman Publishing).

Pollitt, C. (1993) Managerialism and public services (Oxford: Blackwell).

Pollitt, C. and Summa, H. (1997) 'Reflexitive watchdogs? how supreme audit institutions account for themselves', Public Administration, Vo. 75, No. 2, pp. 313-336.

Pollitt, C (1986), 'Beyond the managerial model: the case for broadening performance assessment in government and the public services', Financial Accountability and Management, pp. 155-169.

Pollitt C. (2003) 'Performance audit in Western Europe: trends and choices', Critical Perspectives on Accounting, Vol. 14, No. 1/2, pp. 157-70.

Pollock, A. M., Price, D. and Player, S. (2007) 'An examination of the UK Treasury's evidence base for cost and time overrun data in UK value-for-money policy and appraisal', Public Money and Management, Vol. 27, No. 2, pp. 127-134. 
Porter, B. (1993) 'An empirical study of the audit expectations-performance gap', Accounting and Business research, Vol. 24, No. 93, pp. 49-68.

Porter, B., Simon, J. and Hatherly, D. (1996) Principles of external auditing. (UK: John Woleyand Sons).

Power, M. (1994) The Audit Explosion. (London: DEMOS)

Power, M. (1997) The audit society: rituals of verification, $1^{\text {st }}$ edition. (Oxford: Oxford University Press).

Power, M. (1999) The audit society: rituals of verification, $2^{\text {nd }}$ edition. (Oxford: Oxford University Press).

Power, M. (2000) 'The audit society - second thoughts', International Journal of Auditing, Vol. 4, No. 1, pp. 111-119.

Prowle, M. (2010) Managing and Reforming Modern Public Services. (Harlow: Pearson Education Limited).

Ridley, A. (1996) 'A profession for the twenty century', Internal Auditor, October, pp. 20-26. Senatra, P. T. (1980) Role conflict, role ambiguity, and organisational climate in a public accounting firm‘, The Accounting Review, Vol. 55, No. 4, pp. 594-603.

Sharma, N. (2007) 'Interactions and interrogations: negotiating and performing value for money reports', Financial Accountability and Management, Vol. 23, No. 3, pp. 289-311.

Siegel, G. (2000) 'Business partner and corporate cop: do the roles conflict?' Strategic Finance, Vol. 82, No. 3, pp. 89-90.

Stone-Romero, E. F., Stone, D. L. and Salas, E. (2003) 'The influence of culture on role conceptions and role behaviour in organisations', Applied Psychology: An International Review, Vol. 52, No. 3, pp. 328-362.

Talbot, C. and Wiggan, J. (2010) 'The public value of the National Audit Office', International Journal of Public Sector Management, Vo. 23, No. 1, pp. 54-70.

Tanko, M., Samuel, G. and Dabo, Z. (2010). Value for money audit in Nigerian local government area councils: an empirical examination, Proceedings of the Northeast Business \& Economics Association.

Van Sell, M., Brief, A. P., and Schuler R. (1981) 'Directions for future research role conflict and role ambiguity: Integration of the literature and directions for future research', Human Relations, Vol. 34, No. 1, 43-71.

Wickham, M., and Parker, M. (2007) ${ }^{`}$ Reconceptualising organizational role theory for contemporary organizational contexts', Journal of Managerial Psychology, Vol. 22, No. 5, pp. $440-464$. 
Wolfe, D. M. and Snoek, J. D. (1962) 'A study of tensions and adjustments under role conflict', The Journal of Social Issues, Vol. 18, No. 7, pp. 102-121.

\section{Appendix I: Key research papers on VfM and audit expectation gap including their aims, methods and main findings and interpretations.}

\begin{tabular}{|c|c|c|c|}
\hline Author Name(s) & Study $\operatorname{Aim}(s)$ & Data and Methods & Findings \\
\hline $\begin{array}{l}\text { Funnel and } \\
\text { Wade (2012) }\end{array}$ & $\begin{array}{l}\text { Examine auditors and } \\
\text { auditees relationship } \\
\text { in the context of } \\
\text { performance audit in } \\
\text { Australia }\end{array}$ & $\begin{array}{l}\text { Apply the five } \\
\text { parameters typology of } \\
\text { strategic reactions } \\
\text { developed by Oliver } \\
\text { (1991) } \\
\text { Conduct in-depth } \\
\text { interviews and observe } \\
\text { the auditors and auditees } \\
\text { during the performance } \\
\text { audit exercise }\end{array}$ & $\begin{array}{l}\text { Auditors and members of the Joint } \\
\text { Committee of Public Accounts and } \\
\text { Audit are positive and confident } \\
\text { about the performance audit } \\
\text { outcomes in terms of delivering value } \\
\text { to the auditees. } \\
\text { Auditees have shown resistance } \\
\text { towards some of the performance } \\
\text { audit outcomes as well as the attitude } \\
\text { of auditors. } \\
\text { The relationship between auditors } \\
\text { and auditees is highly complex, } \\
\text { particularly at the micro level of } \\
\text { performance audit practice. }\end{array}$ \\
\hline Sharma (2007) & $\begin{array}{l}\text { Examine interactions } \\
\text { among actors } \\
\text { involved in the } \\
\text { preparation of VfM } \\
\text { audit reports }\end{array}$ & $\begin{array}{l}\text { Use field study at the } \\
\text { National Audit Office. } \\
\text { Apply dramaturgy } \\
\text { metaphors developed by } \\
\text { Goffman (1959) } \\
\text { Informal interviews are } \\
\text { conducted with teams } \\
\text { preparing the audit } \\
\text { reports. }\end{array}$ & $\begin{array}{l}\text { The actors are interacting and } \\
\text { negotiating their position during the } \\
\text { preparation of the VfM reports. } \\
\text { Auditors use different set of language } \\
\text { and texts with auditees and the } \\
\text { members of the Public Accounts } \\
\text { Committee in a manner that meets the } \\
\text { expectations of each party. } \\
\text { Auditors use facts to endorse their } \\
\text { statements in the VfM reports. }\end{array}$ \\
\hline $\begin{array}{l}\text { Chowdhury, } \\
\text { Innes and } \\
\text { Kouhy (2005) }\end{array}$ & $\begin{array}{l}\text { Investigate if there is } \\
\text { an audit expectation } \\
\text { gap between } \\
\text { Comptroller and } \\
\text { Auditor General's } \\
\text { (CAG) auditors and } \\
\text { the users of CAG } \\
\text { reports in } \\
\text { Bangladesh. }\end{array}$ & $\begin{array}{l}\text { Use of questionnaire } \\
\text { based on accountability } \\
\text { theoretical framework. }\end{array}$ & $\begin{array}{l}\text { There are significant differences in } \\
\text { perceptions between CAG auditors } \\
\text { and the users in relation to auditor } \\
\text { independence, competence, reporting } \\
\text { and accountability, performance audit } \\
\text { and audit evidence. }\end{array}$ \\
\hline $\begin{array}{l}\text { Bowerman, } \\
\text { Humphrey and } \\
\text { Owen (2003) }\end{array}$ & $\begin{array}{l}\text { Examine the role of } \\
\text { public audit bodies in } \\
\text { the UK }\end{array}$ & $\begin{array}{l}\text { Review, discuss and } \\
\text { debate key audit papers } \\
\text { and documents and } \\
\text { developments of the UK } \\
\text { public audit practice. }\end{array}$ & $\begin{array}{l}\text { There is conflict over the scope of } \\
\text { power and activities given to the UK } \\
\text { four national audit agencies. } \\
\text { There are number of limitations with } \\
\text { the current public audit practice } \\
\text { including consistency and less focus } \\
\text { on outcomes. }\end{array}$ \\
\hline Morin (2003) & $\begin{array}{l}\text { Examine the role of } \\
\text { VFM auditors as } \\
\text { controllers and } \\
\text { catalysts of } \\
\text { performance } \\
\text { improvement }\end{array}$ & $\begin{array}{l}\text { Adopt interpretivist } \\
\text { approach covering six } \\
\text { case studies of VFM } \\
\text { audits. } \\
\text { Data was collected } \\
\text { through interviews and } \\
\text { analysing of } \\
\text { documentations. }\end{array}$ & $\begin{array}{l}\text { Auditors approach to VfM audit is } \\
\text { influenced by the culture and the } \\
\text { philosophical attitude of the } \\
\text { organisation to whom they belong. } \\
\text { VFM audit is not carried out in the } \\
\text { form of vacuum but rather takes into } \\
\text { account a number of behavioural and } \\
\text { organisational parameters. }\end{array}$ \\
\hline
\end{tabular}




\begin{tabular}{|c|c|c|c|}
\hline & & & $\begin{array}{l}\text { Auditees are more inclined towards } \\
\text { auditors' role as controllers than their } \\
\text { role as catalysts. }\end{array}$ \\
\hline Morin (2001) & $\begin{array}{l}\text { Investigate indicators } \\
\text { of performance and } \\
\text { drivers of success in } \\
\text { the VFM audit }\end{array}$ & $\begin{array}{l}\text { Use of multiple case } \\
\text { study covering six cases } \\
\text { of VFM audits in } \\
\text { Canada. } \\
\text { Conduct interviews and } \\
\text { analyse documentations } \\
\text { from the audit exercise. }\end{array}$ & $\begin{array}{l}\text { Auditees characteristics } \\
\text { (commitment, tolerance and impact } \\
\text { level) directly influence the audit } \\
\text { process. } \\
\text { There is lack of communication } \\
\text { between auditors and auditees leading } \\
\text { to weak influence by auditors and not } \\
\text { achieving the desired outcomes. }\end{array}$ \\
\hline $\begin{array}{l}\text { Lapsley and } \\
\text { Pong (2000) }\end{array}$ & $\begin{array}{l}\text { Examine the practice } \\
\text { of VfM audit in } \\
\text { Scotland }\end{array}$ & $\begin{array}{l}\text { Apply Bourdieu (1977) } \\
\text { reasoning of practice to } \\
\text { VfM audit as perceived } \\
\text { by auditors. } \\
\text { Data was collected from } \\
\text { auditors (elites) over two } \\
\text { set of periods using } \\
\text { specific set of questions } \\
\text { and discussion. }\end{array}$ & $\begin{array}{l}\text { Auditors are positive in terms of the } \\
\text { benefits attained from VfM audits at } \\
\text { both operational and strategic levels } \\
\text { of the audited organisations. } \\
\text { The concept of VfM audit in practice } \\
\text { is still not fully clear because of } \\
\text { different interpretations of what } \\
\text { constitute the best VfM audit among } \\
\text { the auditors. } \\
\text { VfM audit in its current practice does } \\
\text { not fully capture the values of the } \\
\text { audited organisations as some of } \\
\text { them cannot be measured in } \\
\text { monetary terms applied by auditors. }\end{array}$ \\
\hline Power (2000) & $\begin{array}{l}\text { Review the notion of } \\
\text { 'The Audit Society' } \\
\text { asserted by Power } \\
\text { (1999) and the case } \\
\text { for 'audit explosion' }\end{array}$ & $\begin{array}{l}\text { Use of critic and } \\
\text { arguments on the causes } \\
\text { and consequences of the } \\
\text { audit explosion }\end{array}$ & $\begin{array}{l}\text { Audit has an economic and social } \\
\text { dimension, which directly affect the } \\
\text { way it is implemented. } \\
\text { Different interpretations are still } \\
\text { attached to various types of audit } \\
\text { including VFM audit. } \\
\text { Companies are less positive about the } \\
\text { value added by auditors, particularly } \\
\text { on the aspect of efficiency. }\end{array}$ \\
\hline $\begin{array}{l}\text { Koo and Sim } \\
\text { (1999) }\end{array}$ & $\begin{array}{l}\text { Examine auditors- } \\
\text { auditees relationship } \\
\text { and perceptions of } \\
\text { each other }\end{array}$ & $\begin{array}{l}\text { Use relationship } \\
\text { commitment theorem to } \\
\text { test empirically the } \\
\text { relationship between the } \\
\text { audit firm and their } \\
\text { clients }\end{array}$ & $\begin{array}{l}\text { Auditees consider limited variation } \\
\text { existing in the service quality offered } \\
\text { by different audit firms. } \\
\text { Auditors and their clients consider } \\
\text { their relationship as having mutual } \\
\text { benefits to both parties. } \\
\text { Affective commitment results in } \\
\text { better communication and trust } \\
\text { between auditors and their clients. }\end{array}$ \\
\hline
\end{tabular}

\section{Appendix II: The content of the interview}

The following issues were used as guidelines to set-up the interview questions:

- The expectations of the VfM auditor's roles

- Perception of the VfM audit's usefulness. 
- Whether the VfM audit has been perceived as a process of controlling or a means to achieve performance improvement.

- The impact of social factors at the personal, interpersonal and external levels on the effective performance of the VfM audit.

- The materiality of the VfM auditors' findings.

- The truth and fairness of the VfM auditors' reports.

- Client acceptance of the auditor's recommendations.

- The nature of role conflicts in the VfM audit environment. 